\title{
Pedagogical and psychological aspects of educating preschool children in the national spirit
}

\author{
Abdullajonova Dildora Rustamjonovna
}

teacher of Preschool education methods department, Andijan State University. Uzbekistan

\begin{abstract}
The following article deals with the pedagogical and psychological aspects and ways of educating and upbringing preschool children in the national spirit. Pedagogical analysis of the situation in the pedagogical theory and practice of national, spiritual upbringing of children of preschool age showed that, although there are scientific developments and practical experience in this area, they do not correspond to the content of educational reforms in the years of independence. Second, over time, due to ideological change, they have become spiritually obsolete.
\end{abstract}

Keywords:

music. Theatre, fiction, art, kindergarten, preschool children.

Article Received: 18 October 2020, Revised: 3 November 2020, Accepted: 24 December 2020

\section{Introduction}

Nowadays one of the important tasks is to bring up fully developed, physically healthy, mentally and spiritually matured preschool children. The Ministry of Preschool Education of the Republic of Uzbekistan adapted resolution on June 18, 2018 № 1-mh "State requirements for the development of primary and preschool children", and "Ilk Kadam" (First step) preschool educational institution was developed the state curriculum, in which the state requirements for the development of primary and preschool children determines the educational process based on its psychological characteristics.

In pre-school educational institutions, children are mainly trained by school preparation program. That is, knowledge, skills and abilities of each child's age are formed, in which perception, observation, memory, thinking are developed, perceptions of the world of time and spatial concepts, social phenomena are issued as well.

The requirements of the state: the task of educating children on the basis of national, universal and spiritual values, the introduction of effective forms and methods of development are also analyzed.

Therefore, the development of pedagogical and psychological aspects of the upbringing of children of kindergarten age in the national spirit, the development of forms, methods and techniques of upbringing in the national spirit on the basis of modern requirements is of great importance.

Analysis of the relevant literature. Doctor of Pedagogical sciences S. Nishonova includes in the process of spiritual and moral education the followings: humanity, justice, patriotism, faithfulness, conscientiousness, patience, thoughtfulness, friendship, respect, sincerity, national pride, gentleness, kindness, honesty, humility, ability to solve problems independently and others. It mimics a series of exhortations, exhortations, beliefs, comparisons, conversations, debates, counseling, lectures, experiments, examples, explanations, coercion, encouragement, punishment, and other methods in shaping these qualities. (Nishonova S. Upbringing of a perfect person in the development of pedagogical thought of the era of the revival of the East: - Author's abstract of thesis for a doctor of pedagogical sciences. - T .: 1998. - 38 p.)

The three-tiered system of measuring the criteria, indicators, levels and qualities of national upbringing of students, developed by Doctor of Pedagogical Sciences M. Kuronov. The scientist's research is directly and indirectly related to the natural national feeling: patriotism, national pride, 
interethnic dialogue based on the practical unity of scientific and folk pedagogy in the harmonious formation of culture, conscience, national etiquette and national ideological consciousness.

Analyzing the views of Eastern thinkers on the upbringing of children, M. Inomova admits that they also pay special attention to art. She likens art to a swan, emphasizing that we can make children beautiful by making them crafty and at the same time that not learning different trades is a sign of inferiority. Just as a person in the shadow of a swan achieves state and happiness, so do those who have a profession and art [51, 84-85].

In the study of the possibilities of using the resources of Uzbek folk pedagogy in the spiritual and moral upbringing of children in the family, $\mathrm{M}$. Inomova said that "Carving, jewelry, goldsmithing, embroidery, slavery, household items from the types of applied arts that have become a daily necessity among the Uzbek people. In Uzbek families, sewing has been used, firstly, to meet material needs, and secondly, as an important educational tool in educating children in the spirit of love for work, profession, profession "[51, 180-181] (Inomova M. National values in the spiritual and moral upbringing of children in the family . - T .: "Fan" publishing house, 1995. 227 p.). In addition, it should be noted that these classes are also important as a source of aesthetic education.

The organization of spiritual and educational work in educating students of preschool education in the national spirit has a positive effect. The result of spiritual and educational work depends on the effective implementation of the pedagogical influence of the child's spiritual culture and its components. In order to study and analyze the problem in order to ensure these pedagogical conditions, we came up with a new methodological approach to the formation of students' spiritual culture was developed by Doctor of Pedagogical Sciences O. Musurmanova. According to her opinion, the inner spiritual world of an individual consists of a system of basic components such as spiritual need, spiritual interest, spiritual activity and spiritual value. Based on this conceptual approach, we have developed a model of the internal development of the individual in the national, spiritual world

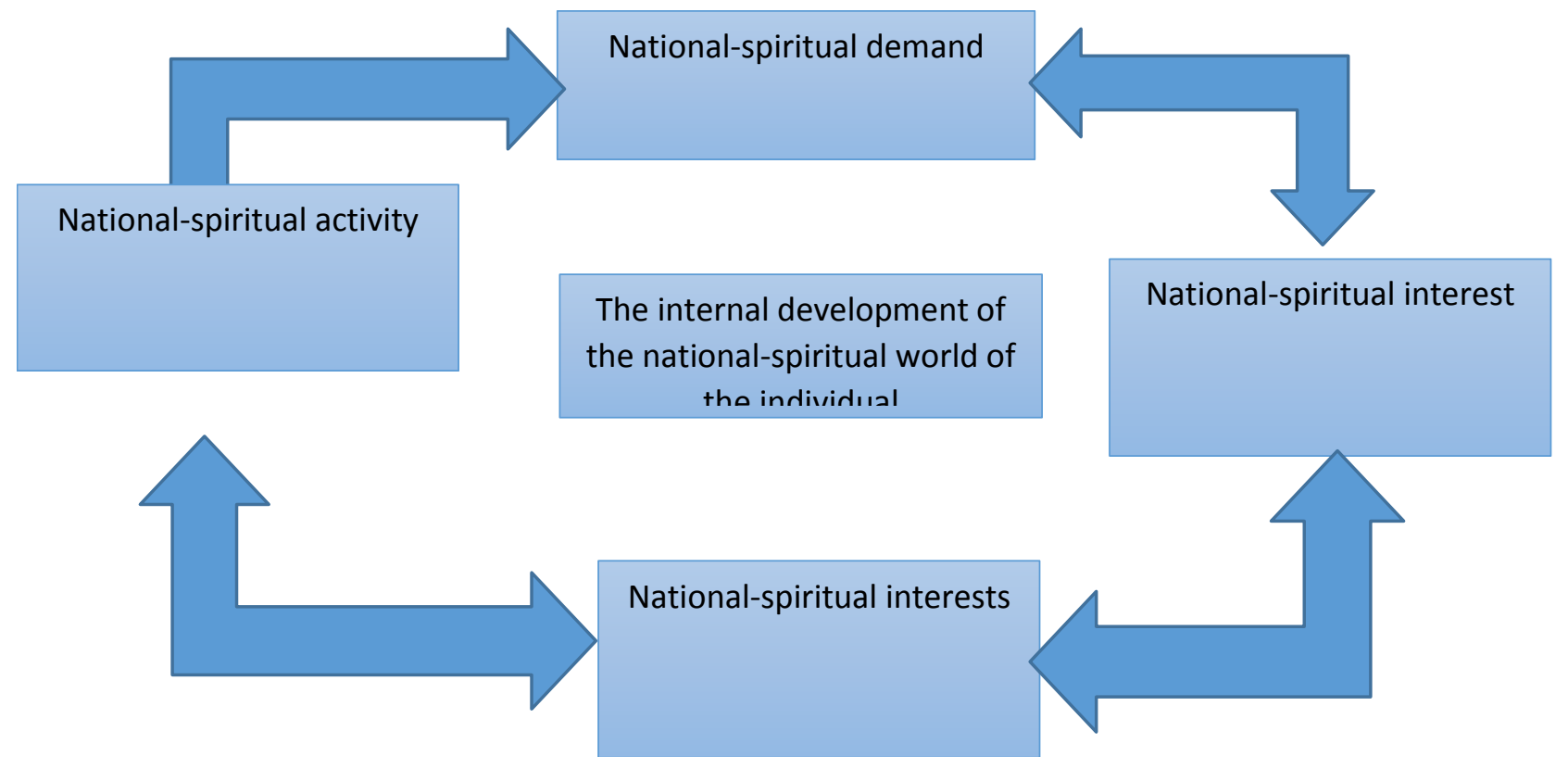

It means that national-spiritual need of the individual creates a national-spiritual interest, which is manifested in the process of the person's activity, and as a result, the national-spiritual 
value is formed. National-spiritual value, in turn, is the basis for the emergence of a high nationalspiritual need. This cycle of national-spiritual development continues uninterrupted.

It is obvious that the upbringing of a person in the national-spiritual spirit lasts from the first age of a child to the end of his life. The educational activity of the teacher, educator in the preschool educational institution plays an important role in the upbringing of the child in the national spirit, and the formation of national concepts.

No matter how much we continue such analyzes, in the theory of Pedagogy there is a problem of formation of national-spiritual concepts, perceptions in preschool children is not specially studied. However, some of the work done in this direction can be used to some extent as a methodological basis.

It is known from pedagogical, psychological research that the main part of children's worldview is formed in their preschool years. Therefore, the readiness of the child for school education is a guarantee of the upbringing of a well-rounded person as a result of the pedagogical activities carried out in the preschool institution. After all, the process of choosing a child's "I" takes place in kindergarten and in the family. Moral and aesthetic perceptions play an important role in the content of the spiritual qualities of the child's worldview.

\section{METHODS}

In order to carry out the organizational and pedagogical correctness of upbringing children of preschool age in the national spirit, the scope of indicators that need to be identified in the first place has been identified. The basics of this are as follows:

1. Determining the level of knowledge of national-spiritual concepts of teachers, educators, and parents.

2. The tendency of teachers, educators, parents to impart knowledge of national-spiritual, aesthetic content to children (wants, does not want, indifferent).
3. The ability of teachers, educators, parents to impart knowledge to children in the formation of national-spiritual, aesthetic ideas, the level of pedagogical knowledge and methodological skills.

4. Awareness of pure aesthetic values and traditions of educators, educators, parents and the ability to tell children about them (for example, folk arts, crafts, theater, cinema, music, fine arts, and others).

5. The commonality (or vice versa) of parental considerations in the education of children in the national, spiritual, and aesthetic context.

6. Living conditions of the child, in which the national, spiritual, aesthetic image is formed.

7. The level of mental, physical, mental development of children of preschool age.

8. Comparative analysis of children's tendencies, interests in the acquisition of national and spiritual concepts, their interests with the interests of teachers, educators, parents.

Traditional pedagogical methods are used to gather information about the indicators to be identified listed above. In particular, the situation of the families involved in the experiment was determined. In this case, the family:

- Composition;

- Financial level;

- Moral condition;

- Lifestyle;

- Existing traditions;

- Gender of children;

- The level of mental and intellectual development;

- Natural tendencies, interests in the artistic and aesthetic context.

The purpose of determining the level of knowledge of teachers, educators, parents in the national-spiritual, and aesthetic context are:

- What do you know about the national spirit, spirituality, and aesthetic education?

- Which of the artistic spheres do you know?

- What types of art can be used in the formation of aesthetic perceptions in children? 
- How do you think the process of forming aesthetic perceptions in children in the family should go?

- Should the formation of children's aesthetic perceptions in the family be organized according to their interests, or should parents themselves determine the direction of children's aesthetic interests?

- When working with children, depending on their age (for example, with 5 or 7 years old) should the content of training be determined separately or not? When asked such questions, their pedagogical management skills in the process of forming aesthetic perceptions in children were identified.

From their results it became clear that in organizing the process of educating children in the national spirit, first of all, it is necessary to proceed from the level of training of teachers, educators, parents in this area.

In determining the content of the experimental work, the level of readiness of parents to provide pedagogical guidance in the process of raising children in the national spirit was taken into account. After all, the readiness of children in the national spirit is reflected in their clothes, behavior, speech, listening and singing of national songs, behavior, requires parents to prepare a unique material for their children, who do not have a clear idea of their national interests. These issues have been in the center of our attention in solving the organizational and pedagogical aspects of the experimental work.

Also, children can use the following techniques creatively:

- The scale of national-spiritual, aesthetic imagination (elements of certain concepts about national toys, national dance, national costumes, beauty are observed, aesthetic imagination is not formed at all);

- The presence of interest in a particular situation, event, item (lifestyle in the appropriate home, festive events, room equipment, family members, from clothing to personal belongings, its level, awareness of interest;
- The presence of national-spiritual, aesthetic feelings in children, attitudes to this or that situation, the presence of psychological processes;

- A sense of enjoyment of national-spiritual, aesthetic content, an aesthetic attitude to it (comments on what he sees, feels, tries to add something to it, etc.);

- To be able to remember the nationalspiritual, aesthetic conditions, to restore them in the memory through imagination and perception, to enrich it to a certain extent;

- The presence of elements of nationalspiritual, aesthetic imagination, which are clearly expressed in the child.

In this direction, after identifying the gaps of educators, educators, we have developed forms and means, methods of educating preschool children in the national spirit, and in this we have made extensive use of creative tasks:

"Methodological methods are related to play and widely used for preschool children. If upbringing (parents in our practice) is created by playful actions, and the artistic material is presented in an interesting form, and there are cases of game-specific competition among children, the child will be more successful in various activities. Continuing this idea, we continued the work by approving some of the opposing methods and taking into account that the methods that make them up complement each other. For example:

- Methods of demonstration and methods of performance, culminating in the educator's speech (explanation and demonstration) and demonstration of works of art;

- Methods that stimulate the growth of conscious approach, skills of analysis and comparison, as well as emotional experiences;

- Demonstration of actions that must be clearly followed and methods of forming independent action;

- The methods of training are aimed at strengthening skills and implying originality of creativity, ingenuity, and variability.

In addition to these methods: 
- Involve children in practical activities, the effective use of game elements in the process, the creation of problematic situations, encourage them to find solutions independently (for example, what color of this or that object corresponds to its appearance?);

- Work together in an aesthetic context (joint discussion of this or that event, object, object, aesthetic pleasure from it);

- Encourage children to increase emotional feelings in the process of aesthetic perception of events, objects;

- Demonstration, implementation, teaching by the teacher, educator, parent, which in one way or another, ensures the development of quality, convincing the child of his strength and abilities;

- Methodological approaches, such as creative and aesthetic independence, encouragement of entrepreneurial activity, should be used in the experimental work.

At the same time, the indicators of the level of education of preschool children in the national spirit of teachers, educators, parents allowed to determine the program of experimental work, methods, tools, techniques, procedures and forms of training. According to him, special recommendations have been developed for teachers and parents, and it is recommended to follow these guidelines for the formation of national-spiritual concepts in children of kindergarten age.

\section{Scientific-theoretical analysis of the results of experimental work.}

Determining the level of effectiveness of the content, style, pedagogical conditions developed for the education of preschool children in the national-spiritual spirit determined the main direction of experimental work. Accordingly, in the second stage of the experimental work, the teacher recommended some developments, methodological guidelines, a system of lessons (activities) for children, prepared for the upbringing, and the experimental work:

- The priority tasks are the formation of pedagogical, psychological knowledge, methodological skills of direct teachers, and educators;

- Secondly, educators must have sufficient information about the structural principles and content of national and spiritual concepts that should be formed in children;

- Third, mastering the methodology of conveying the proposed content to children;

- Fourth, pedagogical management of the process of formation of national-spiritual concepts, if necessary, to make certain corrections, changes in this process, and to make recommendations to the head of research;

- Fifth, forecasting the prospects for changes in children;

- Sixth, to know that each child is a world, at the same time, a world unique to itself, and to act accordingly on the principle of individualization of education);

- Seventh, the ability to draw the right conclusions from the views (results). The results of the observations show that pedagogical knowledge and skills are gradually improved when the educator is provided with the necessary adequate methods in educators.

The first task in the experimental process was to formulate a clear idea of the types of activities that educators use to educate children in the national spirit.

Types of activities can be classified according to their content and essence as follows:

Music is the art form that has penetrated the most deeply into people's lives. If a person (and children) listens to music several times a day, they may not enjoy works of fine arts, theater, and fiction for months and years. In this regard, children sing independently in the family, on the radio or accompanies a song on $\mathrm{TV}$, then sings it, and dances to the tune. At first glance, this seemingly simple type of activity may seem like a simple episode of everyday life. However, the process requires a certain content and style. The fact that girls who are genetically obese, have short arms and legs, and are full of interest in the art of dance, and do not fully recognize anything 
other than dance in the art forms, indicates that the process of forming their aesthetic perceptions is misdirected. For this reason, it is necessary to pay attention to the above in the formation of their aesthetic perception in girls who are passionate about the art of dance. However, this should be done at the expense of high pedagogical tact.

Cinema and theatre the art is distinguished by the most impressive means. Because if a song, a melody is performed for 3-5 minutes, the film "holds" the child's attention to a certain extent from 15 (cartoon) minutes to 1.5 hours. That is why it is necessary to strictly control the production of movies that children watch in the family. After all, it is based on the factors that determine the moral norms of an individual's entire life.

Fiction. Kindergarten, fiction can be called an important tool in the upbringing of children in the family in the national spirit in the spiritual and moral development. In fact it would be right to say they are its elements, because preschoolers don't read novels, short stories, or epics. They will become acquainted with the plots of some folk tales. They memorize passages from poems, know some monologue passages, and riddles. It is important that this direction of aesthetic education is also important for the development of confidence and imagination in children of this age.

In this sense, educators should learn parallelly with acquired knowledge; they should be mobilized to inculcate national, spiritual, moral and aesthetic qualities in children. Indeed, the importance of fiction in the formation and development of not only aesthetic ideas, but also a comprehensive worldview, artistic and intellectual thinking in general is incomparable.

Art activity. In fact, art activities in the early years of children are the most important part of the national, spiritual, aesthetic content, in general, we can say children's conscious behavior. The child begins to draw different lines, shapes without yet developing the ability to speak. Once a certain art skill is formed, they live in this world, creating patterns of visual activity in elementary form and content. It has important educational and pedagogical value as it encourages them to think in their own way. It is important that this process does not take place spontaneously in the child's activities, that is, the child must gradually learn to correctly interpret the "images" he or she creates. The educator, the parent in this process must inculcate in the child's mind the notions of aesthetic content such as line and shape, form and content, color and content, and pedagogically manage this process.

Thus, we consider the results of the distribution of interests of preschool children by type of activity (Table 1).

Table 1

Classification of interests of preschool children in the national spirit by types of activities

\begin{tabular}{|c|c|c|c|c|}
\hline \multirow{2}{*}{$\begin{array}{c}\text { Number of } \\
\text { children } \\
\text { (total) }\end{array}$} & \multicolumn{4}{|c|}{ Type of activity } \\
\hline 196 & 67 & 46 & $\begin{array}{l}\text { Cinema and } \\
\text { theatre }\end{array}$ & Fiction \\
\hline $\begin{array}{c}\text { Total number } \\
\text { in percentage }\end{array}$ & 34,2 & 23,5 & 15,8 & 52 \\
\hline
\end{tabular}

The table shows that the majority of the children surveyed (34.2\%) chose the art of music. However, this figure is very one-sided. In particular, when they say the art of music, they mean a few singers, groups. Among them are Shahzoda, Lola, Munisa, Afruza, the group
"Sitora" (in the later stages of the experiment "Setanho"), Tohir Sodikov, the group "Shahzod".

In the field of theater and cinema, too, they have been limited to mentioning the names of Latin American and South Korean series. They have no idea about the process of creating cinema 
(or theater) as an art form. They have the idea that the film is mostly created by actors.

It was clear from the results that notions in the field of fiction had not been formed either. A similar situation can be seen in the field of visual activity.

The degree of formation of national, spiritual, aesthetic concepts in children in kindergarten was assessed by the categories of "high", "medium" and "low" of traditional forms of performance, which are widely used in pedagogical research.

The activities of children with a high level of national and spiritual understanding reflect on independence, creative imagination, the presence of a certain idea of children. In the work done, in which they have the ability to interpret and defend their ideas have a clear expression, they have the skills to understand the realities of society, nature, human life through national and spiritual concepts, and through these skills can express their attitude to life and can take an analytical approach to the perception of national, and spiritual content. Children in this category are also required to have certain perceptions in society. In particular, they know the basics of the peculiarities of national art in their work: they can use art forms to express artistic and aesthetic concepts in their imagination (to be able to interpret an element of a film or theater in an elementary way, to accompany music or move to its melody, read expressive poetry or describe an image in their imagination) can distinguish works of art, as well as aesthetic categories in nature and objects and use art as a means of communication and demonstrate skills of teamwork.

Children with "moderate" national, spiritual perceptions feel independent in their activities, lack creativity or, conversely, have a certain idea in their work, are able to interpret and defend it when necessary, but in some cases the logical conclusion of the idea does not materialize, and there is lack of regularity, stability in activity. Children in this group know the types of art and are able to express their attitudes to them, distinguish and interpret the categories of national and spiritual concepts in nature and human life, express national and spiritual behavior in any activity, have the ability to work as a team .

Children with national, spiritual and aesthetic perceptions can be divided into two categories. The first category includes children who find it difficult to objectively elevate their aesthetic perceptions. interested in another field. It takes more time to raise them to a medium or high level.

In the second category of children, some of the qualities observed in children belonging to the "upper" or "middle" group are manifested. For example, they have an interest in a certain type of national, spiritual activity. But its content varies. Due to this, it cannot show sufficient results in any field.

Determining the level of formation of national-spiritual concepts in preschool children in kindergarten at the beginning of experimental work gives the following results.

Table 2

In children of preschool age by type of activity

levels of formation of national, spiritual concepts

(before the experiment)

\begin{tabular}{|c|c|c|c|c|c|c|c|c|c|c|c|c|}
\hline \multirow{3}{*}{$\begin{array}{c}\text { Number } \\
\text { of } \\
\text { children }\end{array}$} & \multicolumn{12}{|c|}{ Type of activity } \\
\hline & \multicolumn{3}{|c|}{ Music } & \multicolumn{3}{|c|}{$\begin{array}{l}\text { Cinema and } \\
\text { theatre }\end{array}$} & \multicolumn{3}{|c|}{ Fiction } & \multicolumn{3}{|c|}{ Art } \\
\hline & High & $\begin{array}{l}\text { Med } \\
\text { ium }\end{array}$ & Low & High & $\begin{array}{l}\text { Med } \\
\text { ium }\end{array}$ & Low & High & $\begin{array}{l}\text { Med } \\
\text { ium }\end{array}$ & Low & High & $\begin{array}{l}\text { Med } \\
\text { ium }\end{array}$ & Low \\
\hline 196 & 2 & 27 & 38 & 2 & 20 & 25 & 1 & 12 & 18 & 3 & 19 & 30 \\
\hline
\end{tabular}




\begin{tabular}{|c|c|c|c|c|c|c|c|c|c|c|c|c|}
\hline $\begin{array}{c}(\%) \text { in } \\
\text { percentag } \\
\text { e }\end{array}$ & 1,02 & 13,7 & 19,7 & 1,02 & 10,2 & 12,2 & 0,51 & 6,1 & 9,1 & 1,53 & 9,6 & 15,3 \\
\hline
\end{tabular}

Observations and analysis of the processes showed that the majority of educators do not have the required pedagogical and psychological knowledge and methodological skills. Shortcomings in the timely promotion of positive situations and the selection of others, the rational and appropriate use of favorable conditions have led to a relatively low rate of positive shifts in the process under study.

The analysis showed that another golden rule of pedagogy is important, that is, some educators have failed to serve as role models for their children. They also do not set an example that encourages their children to follow instructions. All of these factors have shown that a certain level of corrective work needs to be carried out in the next stages of the experimental work. Therefore, a number of changes were made to the plans for the next stages of the experimental work.

First of all, the focus was on increasing the communicative activity of educators by increasing the social activity of educators. With the help of specialists, mobile events were organized to improve the pedagogical and psychological knowledge and methodological skills of teachers, educators - on-site seminars for teachers, educators, roundtables, model classes, trainings based on best practices of individual teachers and educators.

Secondly, counseling centers for teachers and educators were established, and the guidelines developed for them were improved.

We present the results of the experimental work in Figure 2.1. The upbringing of children in the national spirit was assessed on the basis of criteria for determining the level of formation of moral and aesthetic ideas. The composition of these criteria consists of the following components:
- To understand that art is a means of forming social consciousness, regardless of its type;

- To know the role of art in understanding the world, the formation of ideas about events and phenomena;

- To treat art in an appropriate way, understanding the role of art in the formation of worldview;

- To be able to use art forms to express the concepts of his imagination (elementary interpretation of a film or theater, accompaniment to music or actions appropriate to its movement, reading expressive poetry, depiction of his or her imagination);

- To be able to express their actions and thoughts through art;

- To be able to use the arts as a means of communication;

- Acceptance of national art as a national pride;

- To know the elementary bases of peculiarities of art forms;

- be able to distinguish works of art into categories "good" and "bad" (as elementary examples of the categories of aesthetics, for example, "beauty" and "ugliness") and be able to understand this conclusion;

- be able to differentiate the features of nationalism in art in an elementary way;

- Perception that the idea is clearly expressed in the work done;

- The ability to interpret and defend their creative ideas;

- The work is done independently;

- To be able to use various means of expression in accordance with the purpose of independent work;

- Demonstration of theoretical imagination and practical skills in the work performed on the chosen type of activity; 
- The ability to subordinate their interests to the interests of the team, the formation of skills of aesthetic activity as a team;

-The presence of elements of aesthetic imagination, creativity and independence in the selected activities;

- The need for a level of understanding of the beauties of society, nature and human life through aesthetic imagination;
-The formation of the attitude to life, lifestyle through aesthetic imagination;

-The need for an analytical approach to the perception of aesthetic content.

Thus, the final results of the experimental work showed the effectiveness of the developed materials, the accuracy of the proposed scientific idea, and some positive results that had been achieved in this regard.

The degree to which children's perceptions of the national spirit have formed final results

\begin{tabular}{|c|c|c|c|c|c|c|c|c|c|c|c|c|c|c|}
\hline \multirow{3}{*}{ № } & \multirow{3}{*}{$\begin{array}{l}\text { Type of } \\
\text { activities }\end{array}$} & \multicolumn{13}{|c|}{ Levels of formation of perceptions in the national spirit } \\
\hline & & \multicolumn{4}{|c|}{ High } & & \multicolumn{4}{|c|}{ Medium } & \multicolumn{4}{|c|}{ Low } \\
\hline & & 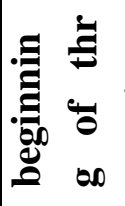 & 寻 & 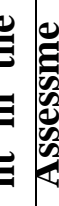 & $\begin{array}{l}\stackrel{\Xi}{ \pm} \\
\Xi \\
\Xi \\
\Xi\end{array}$ & 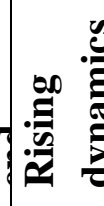 & 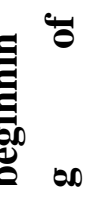 & ๘。 & 昰 & 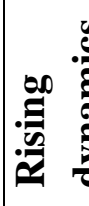 & $\underbrace{\circ}$ & 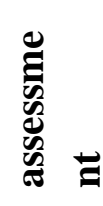 & ฮ્ & 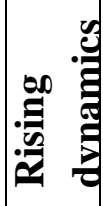 \\
\hline 1 & Music & $2 / 1,2$ & $\begin{array}{l}3 / \\
1, \\
5\end{array}$ & & $\begin{array}{l}7 / 3 \\
6\end{array}$ & 2,4 & $\begin{array}{l}27 / 1 \\
3,7\end{array}$ & $\begin{array}{l}32 / 1 \\
1,3\end{array}$ & $\begin{array}{l}37 / 18, \\
9\end{array}$ & 52 & $\begin{array}{l}38 / 1 \\
9,3\end{array}$ & $\begin{array}{l}32 / 1 \\
6,3\end{array}$ & $\begin{array}{l}27 / 1 \\
3,7\end{array}$ & 5,6 \\
\hline 2 & $\begin{array}{l}\text { Cinema } \\
\text { and } \\
\text { theatre }\end{array}$ & $2 / 1,2$ & $\begin{array}{l}3 / \\
1, \\
5\end{array}$ & & $\begin{array}{l}5 / 2 \\
5\end{array}$ & 1,3 & $\begin{array}{l}20 / 1 \\
0,2\end{array}$ & $\begin{array}{l}23 / 1 \\
1,7\end{array}$ & $\begin{array}{l}21 / 10, \\
7\end{array}$ & 0,5 & $\begin{array}{l}25 / 1 \\
2,7\end{array}$ & $\begin{array}{l}20 / 1 \\
0,2\end{array}$ & $\begin{array}{l}13 / 6, \\
6\end{array}$ & 6,1 \\
\hline 3 & Fiction & $1 / 0,5$ & $\begin{array}{l}2 \\
1, \\
2\end{array}$ & & $\begin{array}{l}5 / 2, \\
5\end{array}$ & 2,0 & $\begin{array}{l}12 / 6 \\
, 1\end{array}$ & $\begin{array}{l}16 / 8, \\
1\end{array}$ & $17 / 8,7$ & 2,6 & $\begin{array}{l}18 / 9, \\
1\end{array}$ & $\begin{array}{l}13 / 6, \\
6\end{array}$ & $9 / 4,6$ & 4,5 \\
\hline 4 & Art & $3 / 1,5$ & $\begin{array}{l}5 \\
2 \\
5\end{array}$ & & $\begin{array}{l}11 / 5 \\
6\end{array}$ & 4,1 & $\begin{array}{l}19 / 9 \\
, 6\end{array}$ & $\begin{array}{l}26 / 1 \\
3,2\end{array}$ & $\begin{array}{l}28 / 14, \\
2\end{array}$ & 4,6 & $\begin{array}{l}29 / 1 \\
4,7\end{array}$ & $\begin{array}{l}21 / 1 \\
0,7\end{array}$ & $\begin{array}{l}16 / 8, \\
1\end{array}$ & 6,6 \\
\hline & TOTAL & $8 / 4,4$ & $\begin{array}{l}13 \\
16 \\
7\end{array}$ & & $\begin{array}{l}28 / 1 \\
4,3\end{array}$ & 9,9 & $\begin{array}{l}78 / 3 \\
9,8\end{array}$ & $\begin{array}{l}97 / 4 \\
9,5\end{array}$ & $\begin{array}{l}103 / 5 \\
2,5\end{array}$ & $\begin{array}{l}12, \\
7\end{array}$ & $\begin{array}{l}110 / \\
56,1\end{array}$ & $\begin{array}{l}86 / 4 \\
3,8\end{array}$ & $\begin{array}{l}65 / 3 \\
3,1\end{array}$ & $\begin{array}{l}29 \\
8\end{array}$ \\
\hline
\end{tabular}

The analysis in the table shows that the results of the final control, the correct organization of the experimental work, the adjustments made to this process after the first control assessment provided the growing dynamics of the positive effect of the final result. This positive effect was confirmed, first of all, by the fact that the number of children with a high level of formation of imagination in the national spirit increased, and the number of children with a low level of formation of aesthetic imagination decreased.

\section{CONCLUSION}

Children acquire to count, add and subtract during pre-school age, and some learn to read and write before attending school. However, if we analyze their activities, we see that the behaviors, interests and aspirations in the national, spiritual, aesthetic context are significant in terms of 
volume. They can be conditionally divided into 4 main groups, as applied during our study: music, theater and cinema, fiction, and art. They can be arranged in such a sequence in terms of both volume and scope of interest in children's aesthetic content activities. However, there is one aspect of the issue that is given less attention, in fact, this activity is the visual activity in the system. From the point of view of recognition, it is in the family that the types of activities are placed in this sequence due to the motivation of the educator.

One of the effective solutions to the problem we have studied is the wider use of the educational and pedagogical potential of the kindergarten in solving the current sociopedagogical problem, such as preparing children of preschool age for school. The formation of national, spiritual concepts, upbringing in the national spirit, upbringing in preschool children in kindergarten, in the family environment is also important as a structural principle. Summarizing and analyzing the results of research in this area allowed to form a conclusion with the following content.

1. It is known from pedagogical and psychological research that a child's worldview is formed mainly at the preschool age. That is why a lot of research has been done on different aspects of preschool education. However, although in fact most of the activities of preschool children are aesthetically pleasing, no special research has been conducted on a number of organizationalpedagogical, methodological and methodological, psychological and physiological aspects of the implementation of these activities in the family. This research is the first attempt in this direction, which can be considered not only as a means of forming aesthetic perceptions in preschool children, but also as a means of preparing children for school education. After all, a child with an aesthetic imagination is psychologically ready for school education with the scope of his observation, the acquisition of certain practical skills. In this sense, it is a topical sociopedagogical problem.
2. Pedagogical analysis of the situation in the pedagogical theory and practice of national, spiritual upbringing of children of preschool age showed that, although there are scientific developments and practical experience in this area, they do not correspond to the content of educational reforms in the years of independence. Second, over time, due to ideological change, they have become spiritually obsolete.

\section{References}

[1] Akramova G.R., Akramova S.R. Developing critical thinking on elementary class pupils is the most important factor for preparing social relationship. JOURNAL OF CRITICAL REVIEWS. ISSN- 2394-5125 VOL 7, ISSUE 17, 2020. [Electronic Resource].

URL: http://www.jcreview.com/?sec=cissue/ (date of access: 23.09.2020).

[2] Ismoilov Rixsitilla Xamidullaevich INNOVATIVE CLUSTER OF PEDAGOGICAL EDUCATION IN XXI CENTURY: PROBLEM, SOLUTION AND RESULT.Journal of Critical Reviews. ISSN2394-5125 Mirzayeva Sayyora Rustamovna. Psychological features of attitudes of students to their own health in conflict situations. journal of critical reviews. ISSN2394-5125 VOL 7, ISSUE 17, 2020. http://www.jcreview.com/?sec=cissue FORMATION OF LOGICAL THINKING SKILLS Karakhonova Oysara Yuldashevna IN PRIMARY SCHOOL STUDENTS (ON THE EXAMPLE OF MATHEMATICS LESSONS). Journal of Critical Reviews. 2020; 7(12): 3071-3076.2020; 7(17): 485-490.

[3] Jamilova B. S. Safarova N. O. Basics of Uzbek Children's Reading. http://www.testmagzine.biz/index.php/testm agzine/article/view/573/513.

[4] Khudaybergenova Zamira Uskakovna. TECHNOLOGY OF TRAINING FUTURE PRIMARY SCHOOL TEACHERS TO IMITATE REAL-LIFE SITUATIONS. JCR. 
2020;

7(12):

3077-

3081. doi:10.31838/jcr.07.12.465

[5] Ochilov Fariddun Izatulloyevich. EDUCATIONAL TECHNOLOGY ON TEACHING NATURAL SCIENCE ACCORDING TO COMPETITIVE APPROACH IN PRIMARY CLASSES // INTERNATIONAL SCIENTIFIC REVIEW OF THE PROBLEMS OF PHILOSOPHY, PSYCHOLOGY AND PEDAGOGY: III International Scientific and Practical Conference ( Boston, USA - 11 July, 2018). https://scientific-

conference.com/h/sborniki/pedagogicheskienauki2/1322-educational-technology.html

[6] Ochilov Fariddun Izatulloyevich. SOCIOMETHODICAL PROBLEMS OF TEACHING PUPILS OF THE PRIMARY SCHOOL NATURAL AND SCIENTIFIC KNOWLEDGE BASED ON THE COMPETENCE APPROACH. https://elibrary.ru/item.asp?id=39142995

[7] Pirniyazova Sholpan Oteniyazovna. THE SYSTEM OF DEVELOPMENT OF COMPETENCIES FOR THE CORRECTION OF THE EDUCATIONAL PROCESS IN STUDENTS OF HIGHER EDUCATION. JCR. 2020; 7(12): 30823088. doi:10.31838/jcr.07.12.466

[8] Polvonov Nurbek Omonboevich. SYSTEM FOR DEVELOPING SKILLS OF DIGITAL TECHNOLOGY IN TEACHING OF THE MODULE "ELECTRICATION OF MINING ENTERPRISES" TO THE STUDENTS. JCR. 2020; 7(12): 30893095. doi:10.31838/jcr.07.12.467

[9] Pulatova Odinahon Khamidovna. THE MECHANISM OF DEVELOPING A CULTURE OF COMMUNICATION IN STUDENTS IN THE EDUCATIONAL PROCESS. JCR. 2020; 7(12): 30963103. doi:10.31838/jcr.07.12.468

[10] Ruziyeva Mohichehra Yokubovna. About color symbols in folklore. JCR. 2020; 7(17): 461-466 $\gg$ Abstract » $\mathrm{PDF} \gg$ doi: 10.31838/jcr.07.17.64;
[11] Safarov Firuz Sulaymonovich, Istamova Shohida Maqsudovna. TYPES OF LEXICAL MEANINGS. Journal of Critical Reviews. 2020; 7(6): 481-484.

[12] Safarova Rohat Gaybullayevna. PEDAGOGICAL TOOLS THAT SERVE THE DEVELOPMENT OF CULTURAL VIEWS IN THE SUBJECTS OF THE EDUCATIONAL PROCESS. JCR. 2020; $7(12)$ : 31043108. doi:10.31838/jcr.07.12.469

[13] Saidova Nilufar Ruzimurotovna. USE FROM MEANS OF INFORMATION AND COMMUNICATION TECHNOLOGIES IN THE FORMATION OF MATHEMATICAL COMPETENCES OF PRIMARY CLASS PUPILS. JCR. 2020; 7(12): 31093114. doi:10.31838/jcr.07.12.470

[14] Samarova Shoxista Rabidjanovna, Rakhmonova Muqaddas Qahramanovna, Mirzarahimova Gulnora, Ikromovna, Maratov Temur Gayrat ugli, Kamilov Bobir Sultanovich. Psychological aspects of developing creative personality and the concept of reduction of creativity to intellect. JCR. 2020; 7(17): 498-505. doi: 10.31838/jcr.07.17.69

[15] Sharifzoda Sardorbek Urozboy Tabib Ugli. THE USE OF AN INTEGRATIVE APPROACH IN THE FORMATION OF BASIC COMPETENCIES IN STUDENTS AS A SOCIO-DIDACTIC NECESSITY. JCR. 2020; 7(12): 31153120. doi:10.31838/jcr.07.12.471

[16] Tilavova Matlab Mukhamadovna, Husenova Aziza Sharipovna, Hakimova Nargiza Supkhonovna. THE SYSTEM OF DEVELOPMENT OF PROFESSIONAL COMPETENCE IN FUTURE PRIMARY SCHOOL TEACHERS. JCR. 2020; 7(13): 4184-4189. doi:10.31838/jcr.07.13.635

[17] Tojiboeva Hilolaxon Makhmutovna. STRATEGIES FOR THE FORMATION AND DEVELOPMENT OF SKILLS STRUGGLING FOR "MASS CULTURE" IN THE SUBJECTS OF CONTINUING 
EDUCATION. JCR. 2020; 7(13): 41904195. doi:10.31838/jcr.07.13.636

[18] Turebekova Guljakhan Adilbekovna. TOOLS FOR DEVELOPING RESPONSIVENESS SKILLS IN PRIMARY SCHOOL STUDENTS. JCR. 2020; 7(12): 31273132. doi:10.31838/jcr.07.12.473

[19] Urinova Nilufar Muhammadjonovna, Tojiboeva Hilolakhon Makhmutovna, Maksudov Ulugbek Kurbonovich. IPROVING THE MECHANISM OF INCREASING THE SOCIAL ACTIVITY OF YOUNG PEOPLE IN THE DEVELOPMENT OF A DEMOCRATIC AND LEGAL SOCIETY. JCR. 2020; 7(12): 3133-3139. doi:10.31838/jcr.07.12.474 